\title{
SUMMARY OF RESULTS FROM MINIMELTER RUN WITH MACROBATCH 3 BASELINE FEED USING FRIT 320 (U)
}

\section{H. Miller}

Westinghouse Savannah River Company

Savannah River Site

Aiken, South Carolina 29808

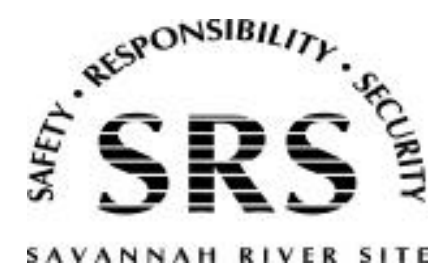


This document was prepared in conjunction with work accomplished under Contract No. DE-AC09-96SR18500 with the U. S. Department of Energy.

\section{DISCLAIMER}

This report was prepared as an account of work sponsored by an agency of the United States Government. Neither the United States Government nor any agency thereof, nor any of their employees, makes any warranty, express or implied, or assumes any legal liability or responsibility for the accuracy, completeness, or usefulness of any information, apparatus, product or process disclosed, or represents that its use would not infringe privately owned rights. Reference herein to any specific commercial product, process or service by trade name, trademark, manufacturer, or otherwise does not necessarily constitute or imply its endorsement, recommendation, or favoring by the United States Government or any agency thereof. The views and opinions of authors expressed herein do not necessarily state or reflect those of the United States Government or any agency thereof.

This report has been reproduced directly from the best available copy.

Available for sale to the public, in paper, from: U.S. Department of Commerce, National Technical Information Service, 5285 Port Royal Road, Springfield, VA 22161, phone: (800) 553-6847, fax: (703) 605-6900

email: orders@ntis.fedworld.gov

online ordering: http://www.ntis.gov/help/index.asp

Available electronically at http://www.osti.gov/bridge

Available for a processing fee to U.S. Department of Energy and its contractors, in paper, from: U.S. Department of Energy, Office of Scientific and Technical Information, P.O. Box 62, Oak Ridge, TN 37831-0062,

phone: (865)576-8401,

fax: (865)576-5728

email: $\underline{\text { reports@ adonis.osti.gov }}$ 
Keywords: 786-A Minimelter Frit 320

\title{
Retention: Permanent
}

\section{SUMMARY OF RESULTS FROM MINIMELTER RUN WITH MACROBATCH 3 BASELINE FEED USING FRIT 320 (U)}

\author{
D. H. Miller
}

Publication Date: April 16, 2002

Westinghouse Savannah River Company

Savannah River Site

Aiken, South Carolina 29808

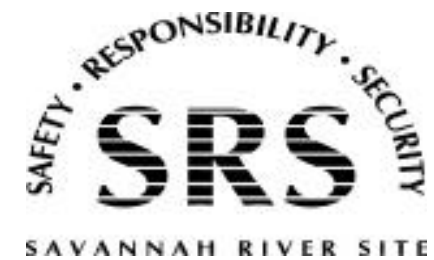


WSRC TR-2002-00188

Rev 0
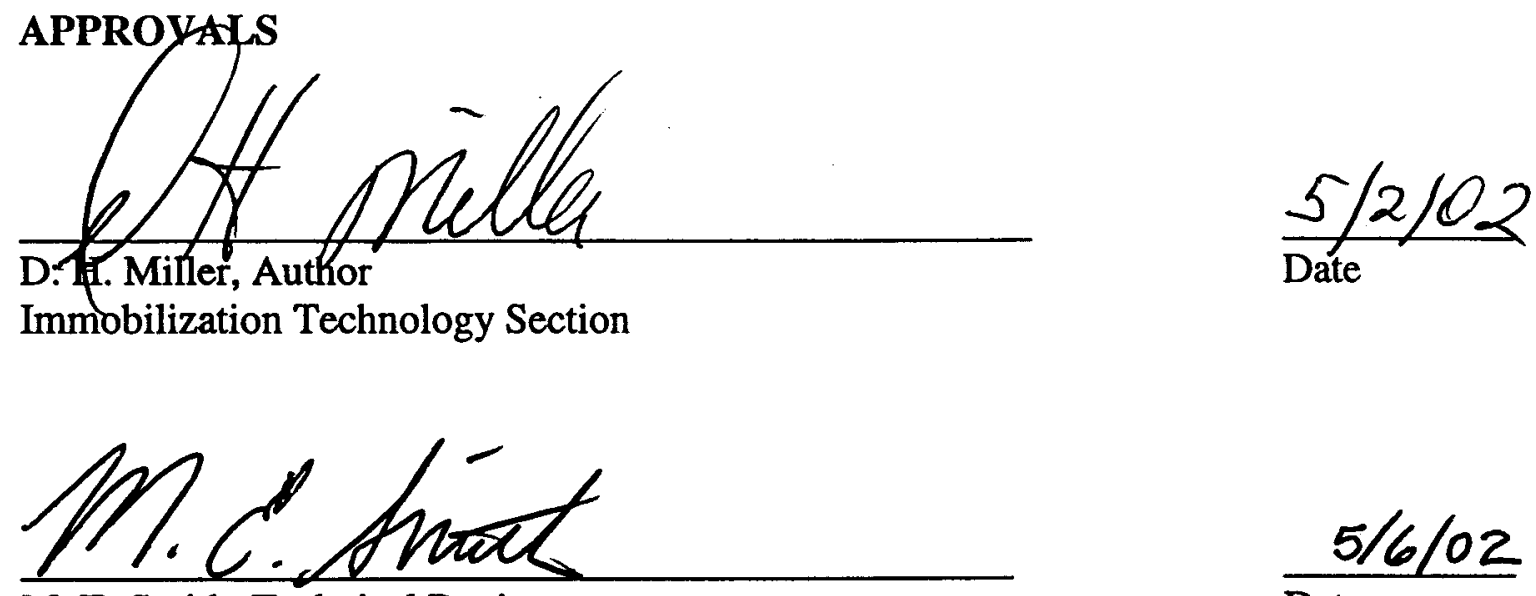

M. E. Smith, Technical Reviewer Immobilization Technology Section

Shaven o Mana

S. L. Marta, Manager

Glass Form \& Process Development Group

ENAatzahul

E. W. Holtzscheiler, Manager

Immobilization Technology Section

$\frac{5 / 15 / d^{2}}{\text { Date }}$

Westinghouse Savannah River Company

Savannah-River Site

Aiken, South Carolina 29808

$5 / 6 / 02$

Date

$5 / 15 / 02$

Date 


\section{TABLE OF CONTENTS}

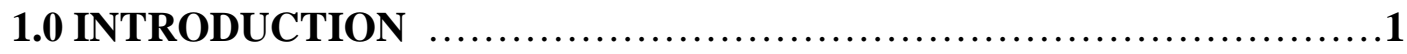

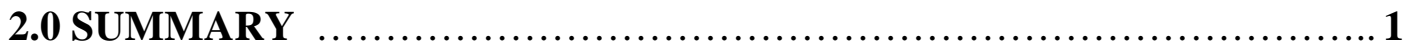

3.0 DISCUSSION ….....................................................

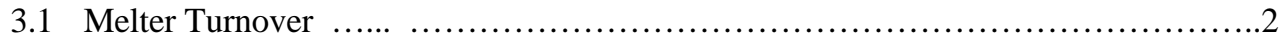

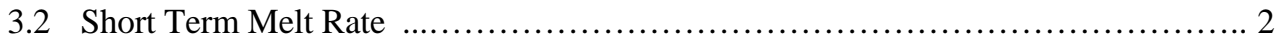

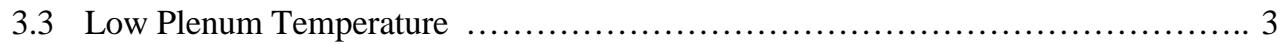

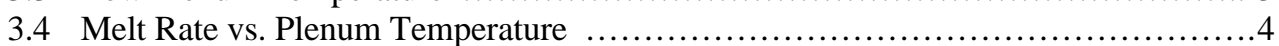

3.5 Extended Melt Rate ........................................................ 6

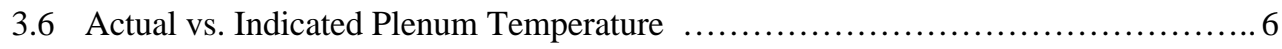

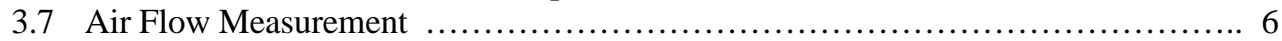

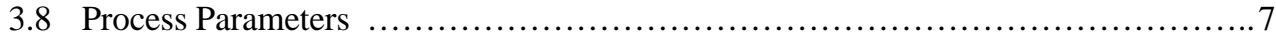

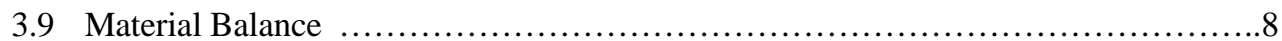

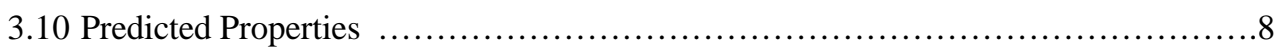

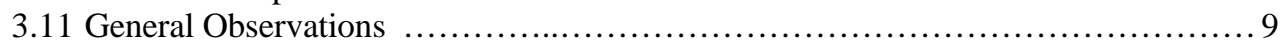

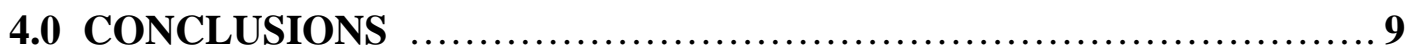

Attachment A: 786-A Minimeter System ......................................... 10

Attachment B: Simulated Feed Composition .....................................11

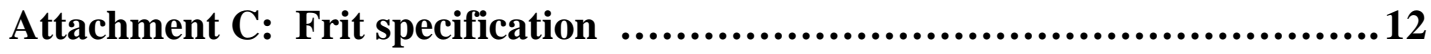

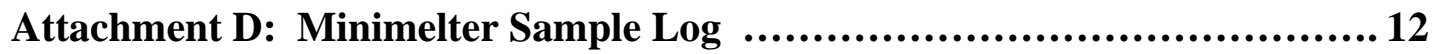

Attachment E: Corrections to 786-A Melter Air Purge and He Tracer Flows.13

Attachment F: Predicted Glass Properties ......................................14

Westinghouse Savannah River Company

Savannah River Site

Aiken, South Carolina 29808

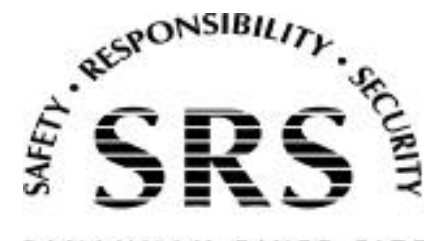


Immobilization Technology Section

Savannah River Technology Center
Document Number: WSRC TR-2002-00188

Revision Number: $0 \quad$ Page 1 of 14

April 16, 2002

\section{SUMMARY OF RESULTS FROM MINIMELTER RUN WITH MACROBATCH 3 BASELINE FEED USING FRIT 320(U)}

\subsection{INTRODUCTION}

This report covers the testing completed as the melter was transitioned from a simulated blend of Tank 8/40(sludge Batch 2) with frit 200 to a simulated blend of Tank 8/40 with frit 320. The same sludge was used to produce both batches of feed in the Glass Feed Preparation System(GFPS). This sludge is referred to as both Sludge Batch 2 and Macrobatch 3 in different reports. The testing was outlined in Task Technical and QA Plan: WSRC-RP-2002-00075, Mini-melter Run with Frit 320 and Sludge Batch 2. The run plan detailing the steps for testing was SRT-GPD-2002-00014: Run Plan for Minimelter with Macrobatch 3 Baseline Feed Using Frit 320 (U). The laboratory notebook used for recording the observations and results was WSRC-NB-2000-00186: 786-A Minimelter. The feed for this melter run was prepared in the GFPS under Task Technical and QA Plan WSRC-RP-2002-00065, GFPS Runs for Minimelter Feed Preparation with Frit 320 (U).

\subsection{SUMMARY}

The general objectives of the run were:

- Determine a relative melt rate for the mini-melter using frit 320.

- Determine off-gas composition under a variety of test conditions.

- Establish operational differences between the use of frit 200 and frit 320.

The objectives of the task plan were met during testing. General melt rate values indicate that frit 320 allows approximately a $20 \%$ higher melt rate when compared to frit 200 . The glass made with frit 320 has a different set of power requirements, but no adverse process problems were discovered. The off-gas generation rates were determined at several plenum temperatures. Data was collected that can be used to estimate the difference between actual and indicated plenum temperature.

\subsection{DISCUSSION}

The 786-A minimelter is joule heated with a one-foot diameter Carborundum Monofax K-3 refractory pot. The vertical electrodes and plenum are made of Inconel 690. There are two vertical Kanthal $^{\mathrm{TM}}$ lid heaters that are capable of supplying 5000 watts each. The overflow spout is heated by a split clam shell $1500 \mathrm{~W}$ resistance heater. The melter is kept under partial vacuum with an air eductor and pressure is controlled with the addition of air. The off-gas passes through a quencher/scrubber and then through a mist eliminator prior to exiting a stack. Sample ports allow the off-gas to be sampled at the melter exit and after the condensate tank. Two gas chromatographs (GC) are used for analysis. A sketch of the melter system is shown in 
Immobilization Technology Section

Savannah River Technology Center
Document Number: WSRC TR-2002-00188

Revision Number: $0 \quad$ Page 2 of 14

April 16, 2002

Attachment A. The campaign was conducted with very few problems caused by feed line pluggage. Continuous pouring at a slightly negative pressure allowed the melter to operate with a minimum number of high glass level alarms.

\subsection{Melter Turnover}

At the start of testing, the melter was full of glass made using frit 200. The specifications for frit 200 and frit 320 are shown in Attachment C. The melter was initially fed for 5 hours at a rate of $\sim 50 \mathrm{cc} / \mathrm{min}$. This was the standard rate used during previous testing and would represent normal operation during a transition between different types of feed. The rate was gradually increased until approximately one melter volume had been poured. Feed samples were taken at least once a day, usually during the transfer from the hold tank to the feed tank. Glass samples were taken at the end of the last pour each day. Feed rates up to $67 \mathrm{cc} / \mathrm{min}$ were used during this transition period. This value was subsequently reduced during the continuous feed portion of the testing. A typical analysis of the two feed batches is shown in Attachment B.

\subsection{Short Term Melt Rate}

The test was conducted by feeding $150 \mathrm{cc} / \mathrm{min}$ for 5 minutes and visually determining the time required to burn off the cold cap. A VCR recorded the surface for comparison to other tests. The duration of volatile generation was also recorded. The melt pool and plenum temperatures were in auto control at $1150^{\circ} \mathrm{C}$ and $850^{\circ} \mathrm{C}$ respectively. The purge air flow was zero and the dilution flow was 160 standard liters per minute. The burn off was determined visually by the absence of any remaining feed on the surface. There is a residual texture to the surface for a long period after feeding, but this was not considered during this test. The feed used during this testing had a $46.9 \mathrm{wt} \%$ solids which is $0.5 \%$ lower than that used in the previous run with frit 200. When all the feed was introduced, there was nearly complete cold cap coverage.

The volatile concentrations were measured using the gas chromatographs (GC). The sample point selected was directly after the addition of the dilution air. Due to low concentrations and short sample times the absolute value of the reading is probably not accurate. Durations were counted for the period that the concentration was above the background value. The duration for both the volatile concentration and visual observation are shown in Table 1 below. The average feed rate is based on the data recording system.

Table 1 -Volatile Generation During Short Term Melt Rate Test

\begin{tabular}{|c|c|c|c|c|}
\hline Test \# & $\begin{array}{c}\text { Feed Rate } \\
\text { cc/min }\end{array}$ & $\begin{array}{c}\text { NO Duration } \\
(\mathrm{min})\end{array}$ & $\begin{array}{c}\text { CO2 Duration } \\
(\mathrm{min})\end{array}$ & $\begin{array}{c}\text { Visual Cold Cap } \\
\text { Burn Off(min) }\end{array}$ \\
\hline 1 & 147 & 9 & 12 & 18 \\
\hline 2 & 144 & 0 & 16 & 24 \\
\hline 3 & 150 & 4 & 21 & 27 \\
\hline Average & 147 & 4.3 & 16.3 & 23 \\
\hline $\begin{array}{c}\text { Previous Frit 200 } \\
\text { Run Average }\end{array}$ & 142 & 12 & 8.3 & 19.3 \\
\hline
\end{tabular}


Immobilization Technology Section

Savannah River Technology Center
Document Number: WSRC TR-2002-00188

Revision Number: $0 \quad$ Page 3 of 14

April 16, 2002

Another observation recorded during the testing was the time required for each volatile component to be detected. Since a water flush is required prior to each feed initiation, there may be a spike in a plot of feed rate vs. time. This can also vary depending on the timing of the flush vs. the one minute frequency of data collection. For purposes of this report, the feed initiation was considered to start at the first of 5 consecutive readings in the range of the set point for feed rate. Table 2 shows the time delay between the initiation of feed and the detection of the volatile component.

Table 2 - Volatile Initiation During Short Term Melt Rate Test

\begin{tabular}{|c|c|c|}
\hline Test \# & $\begin{array}{c}\text { NO Initiation } \\
(\mathrm{min})\end{array}$ & $\begin{array}{c}\text { CO2 Initiation } \\
(\mathrm{min})\end{array}$ \\
\hline 1 & 8 & 5 \\
\hline 2 & na & 6 \\
\hline 3 & 15 & 6 \\
\hline Average & 11.5 & 5.7 \\
\hline $\begin{array}{c}\text { Previous Frit } \\
\text { 200 Run Avg. }\end{array}$ & 2 & 8 \\
\hline
\end{tabular}

The results of the short term testing are difficult to interpret due to problems detecting volatile components during short sample times. The subjective nature of visual observation also makes comparisons difficult. This test appears to be of limited value and will probably be modified or omitted from future runs.

\subsection{Low Plenum Temperature}

This test was performed in an attempt to gather data for flammability calculation verification. The plenum temperature during normal operation is $800-850^{\circ} \mathrm{C}$. There is no hydrogen predicted or detected at these elevated temperatures. Verification of the model requires measurements in the temperature ranges that have predicted hydrogen concentrations. Excess air must be introduced into the plenum to obtain the desired temperatures. This was initially accomplished by removing the sight glass and later by adjusting the melter purge air. After feeding for approximately 30 minutes at $400{ }^{\circ} \mathrm{C}$, the plenum temperature was raised to $\sim 450$ ${ }^{\circ} \mathrm{C}$ by energizing the lid heaters. Off-gas data was collected for approximately 30 minutes before raising the plenum temperature to $500{ }^{\circ} \mathrm{C}$. A feed rate of $\sim 43 \mathrm{cc} / \mathrm{min}$ was maintained while the plenum was operating at that temperature. Several problems with the feed system were encountered during the testing. Replacement of the peristaltic pump hose corrected most of the difficulty. A plot of hydrogen generation versus plenum temperature is shown in Figure 1. Based on the information during this testing, the hydrogen generated at the three temperatures is similar. The verification of the offgas model will be covered under a separate report. 
Immobilization Technology Section Savannah River Technology Center
Document Number: WSRC TR-2002-00188

Revision Number: $0 \quad$ Page 4 of 14

April 16, 2002

\section{Figure 1}

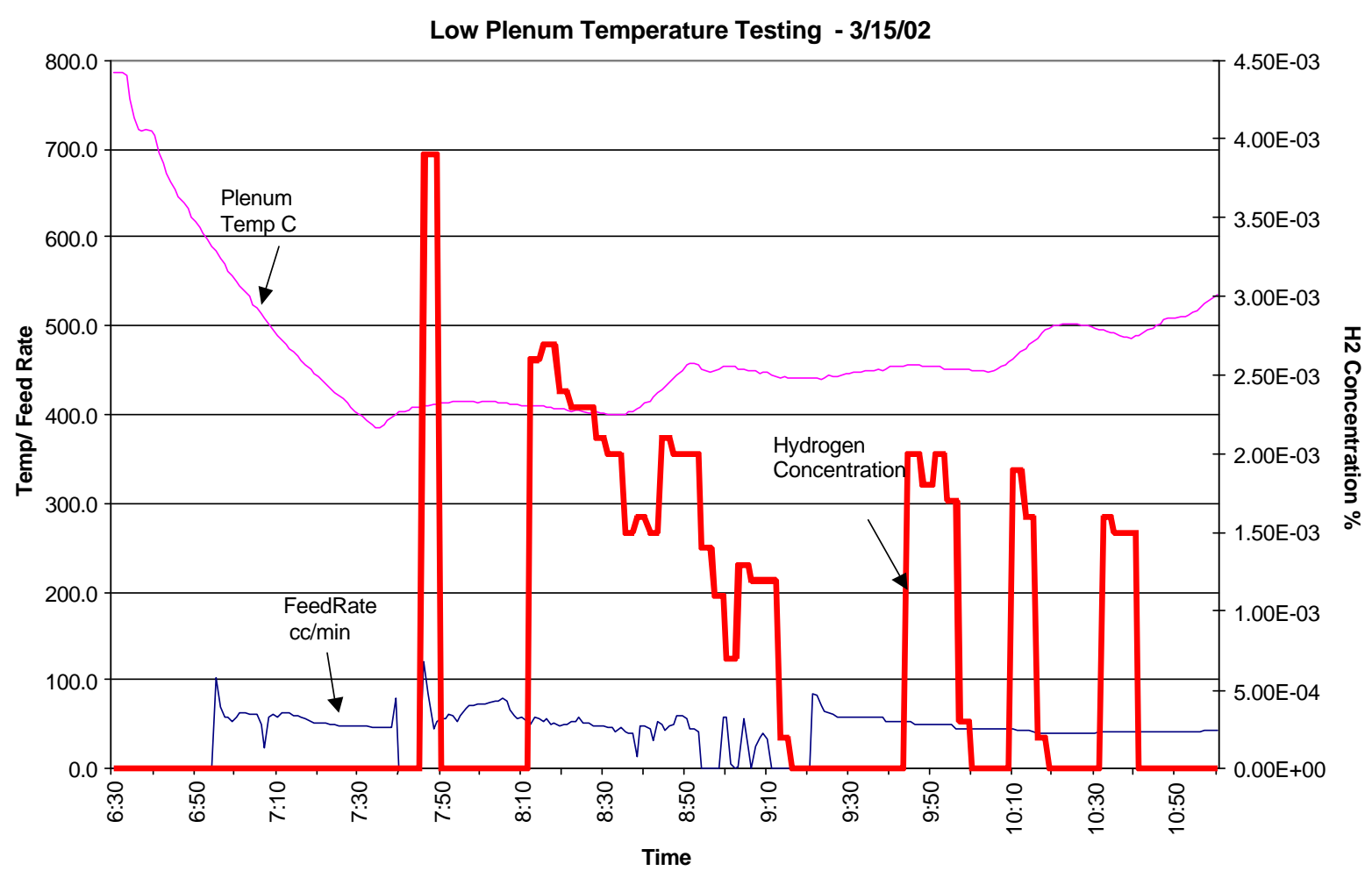

\subsection{Melt Rate vs. Plenum Temperature}

In addition to the low temperature plenum testing described above, two additional runs were made to determine relative melt rate at different temperatures. The plenum temperature was initially lowered to $600{ }^{\circ} \mathrm{C}$ by adding purge air. Once the target temperature was reached, the lid heaters were energized with a set point of $600{ }^{\circ} \mathrm{C}$. The feed rate was initially high to build up the cold cap. The goal during the testing was to maintain a consistent cold cap coverage of $\sim 90 \%$. This is a subjective measurement but generally the presence of several vent holes or a small area of glass constitutes normal coverage. Once steady state was obtained, the plenum temperature was raised to $700{ }^{\circ} \mathrm{C}$ and the test was repeated.

The testing indicated that a steady rate of $\sim 44 \mathrm{cc} / \mathrm{min}$ could be maintained with a plenum temperature of $600^{\circ} \mathrm{C}$ and the glass pool in automatic control with a set point of $1150{ }^{\circ} \mathrm{C}$. The increase to a $700^{\circ} \mathrm{C}$ plenum temperature yielded an estimated steady state feed rate of $\sim 58$ $\mathrm{cc} / \mathrm{min}$. 
Immobilization Technology Section Savannah River Technology Center
Document Number: WSRC TR-2002-00188

Revision Number: $0 \quad$ Page 5 of 14

April 16, 2002

The feed rate vs. plenum temperature for this test is shown in Figure 2. There were feed problems experienced during the testing, especially at the lower temperature. Replacing a pump hose seemed to solve the problem.

Figure 2

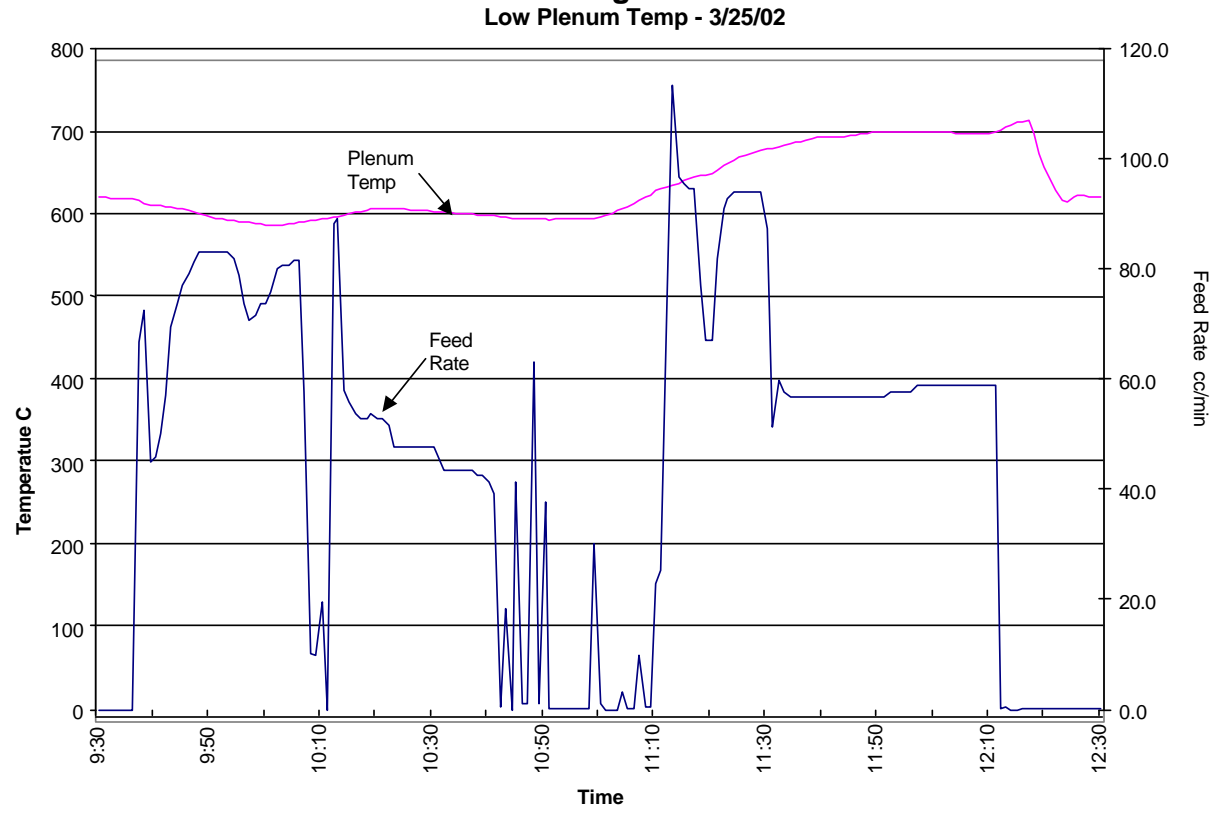

The offgas conditions were monitored during this testing. There were only a couple of very small hydrogen peaks observed during the three hours of testing. A plot of the $\mathrm{CO} 2$ and NO concentrations is shown in Figure 3.

Figure 3

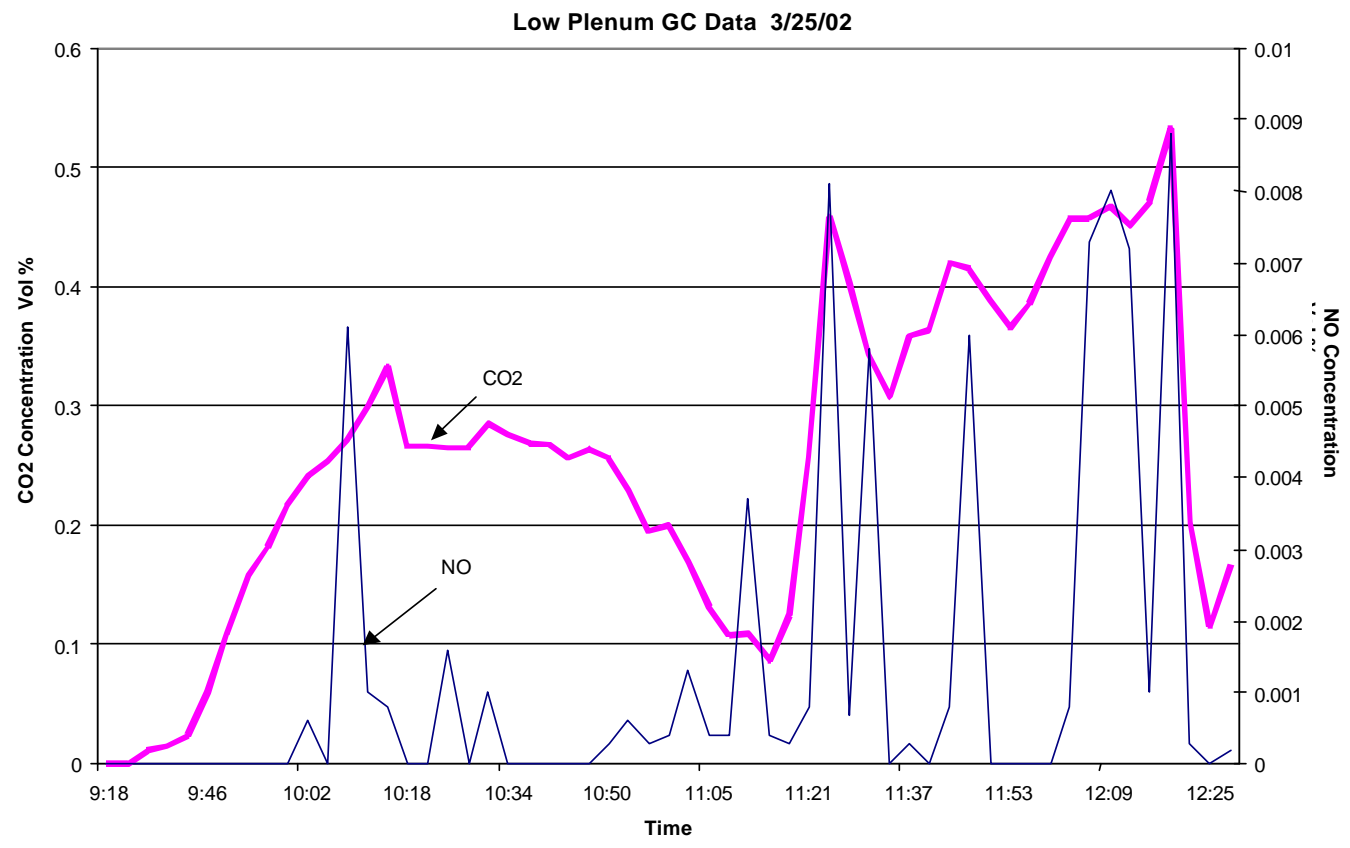


Immobilization Technology Section

Savannah River Technology Center
Document Number: WSRC TR-2002-00188

Revision Number: $0 \quad$ Page 6 of 14

April 16, 2002

\subsection{Extended Melt Rate}

Continuous operation was started by initially feeding with a melter pressure of -4 inwc. Feeding continued until glass began to drip from the pour spout. The pressure was changed to +5 inwc to initiate a steady stream. The set point was then placed at -0.5 inwc and feeding continued for 6 more hours. No problems were observed using the new feed. The cold cap was maintained with similar coverage in both runs. The melter was capable of sustaining a feed rate of $\sim 64 \mathrm{cc} / \mathrm{min}$ using the feed made with frit 320 . This is an improvement over the last campaign using frit 200 , where a maximum sustainable feed rate was $\sim 54 \mathrm{cc} / \mathrm{min}$. Similar feed rates for the frit 320 were also observed during the melter turnover portion of the test. Operating conditions for both runs are shown in Table 3. The glass pool and plenum temperatures were maintained in automatic mode for both tests. Due to an error in the previous report, the plenum temperature for the frit 320 test was held at $850^{\circ} \mathrm{C}$ rather than $800^{\circ} \mathrm{C}$. This is not believed to have a major effect on the melt rate comparison. This is based on the decreasing slope in melt rate when plotted against increasing plenum temperature. A rate of $63 \mathrm{cc} / \mathrm{min}$ at $800^{\circ} \mathrm{C}$ is estimated when graphing the rates at different temperatures.

Table 3 - Melt Rate Conditions

\begin{tabular}{|c|c|c|c|}
\hline Variable & Unit & Frit 320 & Frit 200 \\
\hline Feed Rate & $\mathrm{cc} / \mathrm{min}$ & 64 & 55 \\
\hline Feed Density & $\mathrm{g} / \mathrm{cc}$ & 1.21 & 1.21 \\
\hline Wt \% Solids & $\%$ & 47 & 46.1 \\
\hline Calcine Ratio & & .92 & .915 \\
\hline Glass Melt Rate & $\mathrm{lb} / \mathrm{hr}$ & 4.4 & 3.7 \\
\hline Glass Temperature & ${ }^{\circ} \mathrm{C}$ & 1150 & 1150 \\
\hline Plenum Temperature & ${ }^{\circ} \mathrm{C}$ & 850 & 800 \\
\hline Feed Duration & $\mathrm{hr}$ & 6 & 5 \\
\hline
\end{tabular}

\subsection{Actual vs. Indicated Plenum Temperature}

The actual gas temperature in a melter can differ from the measured temperature for a variety of reasons. The configuration of the thermowell and shine from the glass are two factors. Studies have been conducted to calculate the difference in several melters. Data gathered during a variety of plenum temperatures and feed conditions will allow an estimate of this parameter in the minimelter. Examples of the data to be collected are summarized in Table 4. The actual raw data collected during this testing will be used to calculate the temperature difference. Several data points to complete the table are not available at this time and will be supplied as they become available. This information will be used in off- gas modeling and will be covered in a separate report. 
Immobilization Technology Section

Savannah River Technology Center
Document Number: WSRC TR-2002-00188

Revision Number: $0 \quad$ Page 7 of 14

April 16, 2002

Table 4 - Plenum Temperature Conditions

\begin{tabular}{|l|l|l|l|l|l|l|l|l|l|l|}
\hline $\begin{array}{l}\text { Date-Start/ } \\
\text { Finish }\end{array}$ & $\begin{array}{l}\text { Plenum } \\
\text { Temp } \\
3 \mathrm{~A}\left({ }^{\circ} \mathrm{C}\right)\end{array}$ & $\begin{array}{l}\text { Off-gas } \\
\text { Temp } \\
\mathrm{T} 103\left({ }^{\circ} \mathrm{C}\right)\end{array}$ & $\begin{array}{l}\text { Off-gas } \\
\begin{array}{l}\text { Flow } \\
\text { scfm }\end{array}\end{array}$ & $\begin{array}{l}\text { Purge } \\
\text { Air } \\
\text { slm }\end{array}$ & $\begin{array}{l}\text { Dilution } \\
\text { Air } \\
\text { slm }\end{array}$ & $\begin{array}{l}\text { CO2 flow } \\
\text { \#Mole/min }\end{array}$ & $\begin{array}{l}\text { Feed } \\
\text { Rate } \\
\text { cc/min }\end{array}$ & $\begin{array}{l}\text { Feed } \\
\% \\
\text { Solids }\end{array}$ & $\begin{array}{l}\text { Feed } \\
\text { Density } \\
\mathrm{g} / \mathrm{cc} *\end{array}$ & $\begin{array}{l}\text { Formate } \\
\mathrm{mg} / \mathrm{l}\end{array}$ \\
\hline \hline 3/14 -11:30/17:30 & 850.1 & 127.5 & 9.4 & 0 & 161 & $5.0 \mathrm{E}-2$ & 64.2 & 46.9 & 1.35 & 20400 \\
\hline $3 / 15-9: 25 / 10: 05$ & 450.7 & 135.8 & 12.1 & 150 & 28 & $2.9 \mathrm{E}-2$ & 52.7 & 46.9 & 1.35 & 20400 \\
\hline $3 / 25-11: 30 / 12: 10$ & 694.7 & 155.5 & 7.6 & 108 & 30 & $3.8 \mathrm{E}-2$ & 57.7 & 46.1 & 1.35 & 22900 \\
\hline $3 / 13-15: 27 / 20: 20$ & 849.8 & 108.7 & 7.5 & 0 & 161 & $4.7 \mathrm{E}-2$ & 65.2 & 46.9 & 1.35 & 21000 \\
\hline
\end{tabular}

* Density is estimated from weight and displacement in SRAT and hold tank

\subsection{Air Flow Measurement}

The off-gas flow was calculated using a helium tracer gas that was detected by the gas chromatograph. A known amount of helium was introduced into the off-gas line prior to the sample port. The helium concentration was measured and the total flow calculated. The known air supplies to the off-gas line prior to the sample port are the melter purge and the dilution air. Testing prior to feeding allowed the inleakage to be estimated since it would be the only other source of air not being intentionally supplied. MKS flow meters were calibrated and installed to measure the purge and dilution air flows. Since the flow meters were calibrated with equipment certified at STP, a correction factor had to be used. The helium flow meter was checked using water displacement in a graduated flask. Actual helium flow was higher than indicated and a correction factor was added in the calculation. The correction factors used are shown in Attachment E. Testing after the run indicates that there is approximately a $2 \mathrm{scfm}$ inleakage in the melter.

\subsection{Process Parameters}

Data collection occurred automatically during testing. Additional information was recorded in the laboratory notebook, including setpoint and output changes. Table 5 represents average values during normal and idle operation for both frits. The idle parameters were taken from a 24 hour period several days after the completion of testing for each frit. The feeding parameters were taken during the extended melt rate portion of each test. The power settings required during idle and feeding periods indicate a difference in electrical resistivity between the two glasses. Glass made with frit 320 exhibits a lower resistance. Samples have been submitted to PNNL for electrical resistivity measurements. 
Immobilization Technology Section

Savannah River Technology Center
Document Number: WSRC TR-2002-00188

Revision Number: $0 \quad$ Page 8 of 14

April 16, 2002

Table 5 - Average Melter Parameters

\begin{tabular}{|l|l|l|l|l|l|}
\hline Variable & Unit & $\begin{array}{l}\text { Frit 200 } \\
\text { Idle }\end{array}$ & $\begin{array}{l}\text { Frit 320 } \\
\text { Idle }\end{array}$ & $\begin{array}{l}\text { Frit 200 } \\
\text { Operating }\end{array}$ & $\begin{array}{l}\text { Frit 320 } \\
\text { Operating }\end{array}$ \\
\hline \hline Electrode & $\mathrm{Kw}$ & 3.9 & 4.6 & 3.9 & 5.1 \\
\hline Electrode & $\mathrm{Amp}$ & 141.5 & 174.7 & 143.6 & 186.3 \\
\hline Electrode & Volt & 29.4 & 25.2 & 27.2 & 25 \\
\hline Glass Pool & ${ }^{\circ} \mathrm{C}$ & 1158 & 1141 & 1150 & 1150 \\
\hline Lid Heater & $\mathrm{Kw}$ & $\mathrm{NA}$ & $\mathrm{NA}$ & 6.1 & 5.9 \\
\hline Lid Heater & $\mathrm{Amp}$ & $\mathrm{NA}$ & $\mathrm{NA}$ & 76.1 & 76.6 \\
\hline Lid Heater & $\mathrm{V}$ olt & $\mathrm{NA}$ & $\mathrm{NA}$ & 79.5 & 79.9 \\
\hline Plenum Temp & ${ }^{\circ} \mathrm{C}$ & 780 & 804 & 800 & 850 \\
\hline Feed Rate & $\mathrm{cc} / \mathrm{min}$ & $\mathrm{NA}$ & $\mathrm{NA}$ & 55 & 64 \\
\hline Date of Data & & $7 / 30 / 01$ & $4 / 02 / 02$ & $7 / 26 / 01$ & $3 / 14 / 02$ \\
\hline Duration & Hours & 24 & 24 & 5 & 6 \\
\hline
\end{tabular}

\subsection{Material Balance}

In order to confirm the data collected during the run, a material balance was performed at several conditions. Calculations for two conditions are shown below. A feed slurry density of 1.4 was assumed for both all calculations.

$\mathrm{CO}_{2}$ Balance

Test date 3/13 from 15:27 To 20:24

$\mathrm{CO}_{2}$ generation from feed:

$\frac{65.2 \mathrm{ml}}{\min } \times \frac{1.4 \mathrm{~g}}{\mathrm{ml}} \times \frac{21000 \mathrm{mg} \mathrm{COOH}}{\mathrm{kg} \mathrm{total}} \times \frac{1 \mathrm{~kg}}{1000 \mathrm{~g}} \times \frac{1 \mathrm{~mol} \mathrm{CO} 2}{45 \mathrm{~g}} \times \frac{\mathrm{g}}{1000 \mathrm{mg}}=\frac{4.2 \mathrm{E}-2 \mathrm{~mole}}{\min }$

$\mathrm{CO}_{2}$ detected in off-gas:

$\frac{0.005034 \mathrm{~mol} \mathrm{CO}}{\text { mol off-gas }} \times \frac{7.5 \mathrm{scf} \text { off-gas }}{\mathrm{min}} \times \frac{\mathrm{lbmol}}{359 \mathrm{scf}} \times \frac{453.6 \mathrm{~mol}}{\mathrm{lb} \mathrm{mol}}=\frac{4.7 \mathrm{E}-2 \mathrm{~mole}}{\mathrm{~min}}$

$\mathrm{CO}_{2}$ Balance:

Test date $3 / 14$ from 11:30 to 17:30

$\mathrm{CO}_{2}$ generation from feed:

$\frac{64.2 \mathrm{ml}}{\min } \times \frac{1.4 \mathrm{~g}}{\mathrm{ml}} \times \frac{20500 \mathrm{mg} \mathrm{COOH}}{\mathrm{kg} \mathrm{total}} \times \frac{1 \mathrm{~kg}}{1000 \mathrm{~g}} \times \frac{\mathrm{mol} \mathrm{CO} 2}{45 \mathrm{~g}} \times \frac{\mathrm{g}}{1000 \mathrm{mg}}=\frac{4.0 \mathrm{E}-2 \mathrm{~mol}}{\min }$

$\mathrm{CO}_{2}$ detected in off-gas:

$\frac{0.00426 \mathrm{~mol} \mathrm{CO}}{\text { mol off-gas }}=\frac{9.4 \mathrm{scf} \text { off-gas }}{\mathrm{min}} \times \frac{\mathrm{lbmol}}{359 \mathrm{scf}} \times \frac{453.6 \mathrm{~mol}}{\mathrm{lb} \mathrm{mol}}=\frac{5.0 \mathrm{E}-2 \mathrm{~mole}}{\mathrm{~min}}$ 
Immobilization Technology Section

Savannah River Technology Center
Document Number: WSRC TR-2002-00188

Revision Number: $0 \quad$ Page 9 of 14

April 16, 2002

\subsection{Predicted Properties}

The analyses from 4 pour samples of the run were used to predict the properties of the glass. The results indicate that the estimated values for liquidus, viscosity, homogeneity, and durabilty all fall within the accepted ranges using the PAR criteria. Both the current and new liquidus models were used. The increasing sample number indicates transition between frit 200 and frit 320 glass. Attachment D shows the sample log kept during the run. The results for all properties are shown in Attachment $\mathrm{F}$ for reference. The values predicted by the new liquidus model indicate that higher sludge loading could be achieved with frit 320 and still stay within the limits. The new model incorporates sodium, lithium and potassium into the calculation. The effect of this can be seen in the relationship between $\Sigma$ alkali and liquidus. The new model is described in WSRC- TR-2001 -00520 and the limits for the parameters are listed in WSRCTR-1995-00364, Rev 3.

\subsection{General Observations}

The use of the new feed tube during the testing greatly improved the reliability of the system. Long runs could be made without the need to rod the feed tube. Continuous pouring also allowed the operation of the melter with very few high glass pool level alarms. Operation for long periods at low plenum temperature still continues to be a problem. Two water leaks were discovered during the run. One was on the \#1 electrode clamp, which required the water to be shut off during most of the testing. Occasionally during the high feed rate test, the water was turned on briefly to bring the clamp temperature below the alarm point. There was a second leak in the rotometer supplying the feed tube flush water. This valve had to be opened manually prior to and after each feed initiation or stoppage. The rotometer can be replaced during an idle period, but the clamp leak will require a melter outage.

\subsection{CONCLUSIONS}

The results indicate that glass made with frit 320 melts at a rate $\sim 20 \%$ faster than that using frit 200. This is in line with results from small scale testing. The run also showed that there were no operational problems associated with processing the frit 320 . The glass produced has predicted properties within the acceptable range. A lower electrical resistance is verified by the power settings on the melter during both idle and feeding conditions. 
Immobilization Technology Section Savannah River Technology Center
Document Number: WSRC TR-2002-00188

Revision Number: $0 \quad$ Page 10 of 14

April 16, 2002

\section{Attachment A}

\section{6-A Minimelter System}

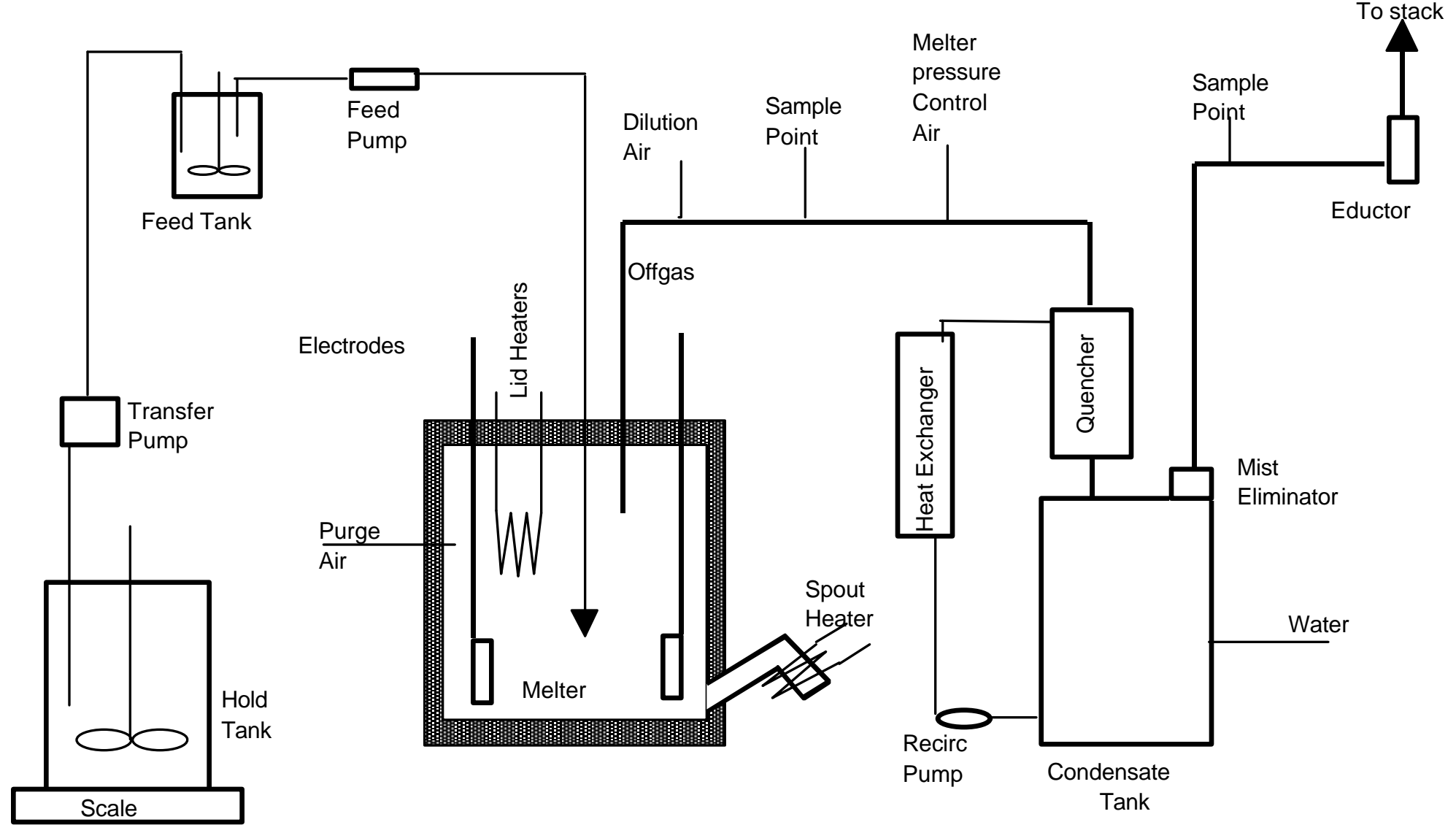


Immobilization Technology Section

Savannah River Technology Center
Document Number: WSRC TR-2002-00188

Revision Number: $0 \quad$ Page 11 of 14

April 16, 2002

\section{Attachment B - Simulated Feed Composition}

\begin{tabular}{|c|c|c|}
\hline $\begin{array}{l}\text { Oxide } \\
\text { Wt \% }\end{array}$ & $\begin{array}{l}\text { Frit 200 } \\
\text { Feed } \\
\text { Sample } \\
\text { MMF009 }\end{array}$ & $\begin{array}{l}\text { Frit 320 } \\
\text { Feed } \\
\text { Sample } \\
\text { MMF024 }\end{array}$ \\
\hline \hline $\mathrm{Al}$ & 2.77 & 2.67 \\
\hline $\mathrm{B}$ & 2.66 & 1.87 \\
\hline $\mathrm{Ba}$ & 0.092 & 0.084 \\
\hline $\mathrm{Ca}$ & 0.924 & 0.688 \\
\hline $\mathrm{Cr}$ & 0.924 & 0.083 \\
\hline $\mathrm{Cu}$ & 0.046 & 0.030 \\
\hline $\mathrm{Fe}$ & 7.85 & 8.61 \\
\hline $\mathrm{K}$ & 0.143 & $<0.010$ \\
\hline $\mathrm{Li}$ & 1.56 & 2.73 \\
\hline $\mathrm{Mg}$ & 0.915 & 0.026 \\
\hline $\mathrm{Mn}$ & 0.866 & 0.828 \\
\hline $\mathrm{Na}$ & 8.33 & 9.22 \\
\hline $\mathrm{Ni}$ & 0.433 & 0.469 \\
\hline $\mathrm{P}$ & 0.035 & 0.029 \\
\hline $\mathrm{Pb}$ & 0.062 & 0.058 \\
\hline $\mathrm{Pd}$ & 0.011 & $<0.010$ \\
\hline $\mathrm{Rh}$ & 0.006 & $<0.010$ \\
\hline $\mathrm{Ru}$ & 0.012 & 0.017 \\
\hline $\mathrm{Si}$ & 23.1 & 25.9 \\
\hline $\mathrm{Zn}$ & 0.126 & - \\
\hline $\mathrm{Zr}$ & 0.202 & 0.165 \\
\hline & & \\
\hline
\end{tabular}


Immobilization Technology Section Savannah River Technology Center
Document Number: WSRC TR-2002-00188

Revision Number: $0 \quad$ Page 12 of 14

April 16, 2002

\section{Attachment C - Frit Specification}

\begin{tabular}{|c|c|c|}
\hline Component & Frit 200 (wt \%) & Frit 320 (wt \%) \\
\hline $\mathrm{B} 2 \mathrm{O} 3$ & 12 & 8 \\
\hline $\mathrm{Li} 2 \mathrm{O}$ & 5 & 8 \\
\hline $\mathrm{Na} 2 \mathrm{O}$ & 11 & 12 \\
\hline $\mathrm{SiO} 2$ & 70 & 72 \\
\hline $\mathrm{MgO}$ & 2 & 0 \\
\hline Total & 100 & 100 \\
\hline
\end{tabular}

\section{Attachment D - Sample Log}

\begin{tabular}{|l|c|l|}
\hline MMF 021 & $3 / 13 / 02$ & Macrobatch 3 feed simulant with frit 320 -collected at feed tank \\
\hline MMG 022 & $3 / 13 / 02$ & Glass pour sample after one melter turnover \\
\hline MMF 023 & $3 / 14 / 02$ & Macrobatch 3 feed simulant collected at feed tank \\
\hline MMF 024 & $3 / 14 / 02$ & Transfer to feed tank after transfer from drum to hold tank \\
\hline MMG 025 & $3 / 14 / 02$ & Power pour at end of continuous testing \\
\hline MMG 026 & $3 / 20 / 02$ & Frit 304 preshipment sample \\
\hline MMG 027 & $3 / 20 / 02$ & Frit 320 final preshipment sample \\
\hline MMG 028 & $3 / 20 / 02$ & Glass from bucket under spout after compeltion of testing $(3 / 15 / 02)$ - drips \\
\hline MMF 029 & $3 / 25 / 02$ & Feed during transfer from hold to feed tank \\
\hline MMF 030 & $3 / 25 / 02$ & Upper feed tank during 600 degree plenum test - thick \\
\hline MMG 031 & $3 / 25 / 02$ & Pour sample at end of run \\
\hline & & \\
\hline
\end{tabular}


Immobilization Technology Section

Savannah River Technology Center
Document Number: WSRC TR-2002-00188

Revision Number: $0 \quad$ Page 13 of 14

April 16, 2002

\section{Attachment E}

\section{Corrections To 786-A Melter Air Purge and Helium Tracer Flows}

Correction to He tracer flow, based on volume per time data taken.

$500 \mathrm{ml}$ of He was collected in 84 seconds.

The flowmeter read $295 \mathrm{ml} / \mathrm{min}$. The temperature of the He was approximately $29.4{ }^{\circ} \mathrm{C}$. The correction factor $f$ is then:

$$
f=\frac{\frac{500 \mathrm{ml}}{84 \mathrm{sec}} \times \frac{60 \mathrm{sec}}{\min } \times \frac{273.16 \mathrm{~K}}{273.16+29.4 \mathrm{~K}}}{295 \mathrm{ml} / \mathrm{min}}=\mathbf{1 . 0 9 3}
$$

The resulting flow reading for the He tracer is then in standard $\mathrm{ml} / \mathrm{min}$, where standard conditions are $1 \mathrm{~atm}$ and $0{ }^{\circ} \mathrm{C}$.

The MKS flowmeters for measuring the Melter Purge Air and Dilution Air were calibrated with $29.92 \mathrm{inHg}(1 \mathrm{~atm})$ and $70{ }^{\circ} \mathrm{F}$ as the standard conditions. The correction factor $k$ is then:

$$
k=\frac{273.16 \mathrm{~K}}{273.16+21.11 \mathrm{~K}}=\mathbf{0 . 9 2 8 3}
$$

The resulting flow readings for the air purges are then in standard L/min (slpm), where standard conditions are $1 \mathrm{~atm}$ and $0{ }^{\circ} \mathrm{C}$. To convert to scfm, divide by 28.316847 .

Example using data collected on 7/19/01:

Dilution Air flowrate reading $\sim 6.0 \mathrm{cfm}$

Melter Air purge flowrate reading $=0$

He tracer flowrate reading $=295 \mathrm{ml} / \mathrm{min}$

He concentration in offgas from gas chromatograph $=0.2 \pm 0.05 \mathrm{vol} \%$

Melter pressure $>0$ inwc (no air inleakage)

Corrected Dilution Air flowrate = $\mathbf{5 . 5 7} \mathrm{scfm}$

Corrected He tracer flowrate $=322.4 \mathrm{ml} / \mathrm{min}$

Calculated Offgas Flowrate $=\frac{322.4 \mathrm{ml} / \mathrm{min}}{\frac{0.20 \mathrm{vol} \%}{100}} \times \frac{\mathrm{L}}{1000 \mathrm{ml}} \times \frac{\mathrm{ft}^{3}}{28.316847 \mathrm{~L}}=\mathbf{5 . 6 9} \mathrm{scfm}$ 
Immobilization Technology Section Savannah River Technology Center
Document Number: WSRC TR-2002-00188

Revision Number: $0 \quad$ Page 14 of 14

April 16, 2002

\section{Attachment F - Predicted Glass Properties}

\begin{tabular}{|l|l|l|l|}
\hline Sample ID & $\begin{array}{c}\text { Viscosity } \\
\text { (Poise) }\end{array}$ & Homogeneity & $\begin{array}{l}\text { Pred NL }^{*} \\
{[\mathrm{~B}(\mathrm{~g} / \mathrm{L})]}\end{array}$ \\
\hline \hline MMG 020 & 92.90 & 232.9 & 0.375 \\
\hline MMG 022 & 71.47 & 232.2 & 0.577 \\
\hline MMG 025 & 62.09 & 232.0 & 0.686 \\
\hline MMG 028 & 56.08 & 230.9 & 0.832 \\
\hline
\end{tabular}

* Predicted PCT

\begin{tabular}{|c|c|c|c|c|}
\hline Sample ID & $\begin{array}{l}\text { Current } \\
\text { Liquidus }\end{array}$ & $\begin{array}{c}\text { New } \\
\text { Liquidus }\end{array}$ & Al203 & EAlkali \\
\hline & $\left({ }^{\circ} \mathrm{C}\right)$ & $\left({ }^{\circ} \mathrm{C}\right)$ & (mass fraction) & (mass fraction) \\
\hline MMG 020 & 990.5 & 1003.8 & 0.0614 & 0.1546 \\
\hline MMG 022 & 987.6 & 919.6 & 0.0559 & 0.1696 \\
\hline MMG 025 & 990.6 & 900.2 & 0.0529 & 0.1753 \\
\hline MMG 028 & 988.7 & 907.5 & 0.0514 & 0.1809 \\
\hline
\end{tabular}

